\title{
Management of Quality-Based Education in Facing Asian Economic Community
}

\author{
Abduloh \\ Department of Physical Education, Health, and Recreation \\ Universitas Singaperbangsa Karawang, Indonesia \\ abduloh175@gmail.com
}

\author{
Yousep Bani Ahmad \\ Department of Physical Education, Health, and Recreation \\ Universitas Singaperbangsa Karawang, Indonesia \\ yousef.baniahmad@fkip.unsika.ac.id
}

\begin{abstract}
Management is one element to achieve aims and objectives of education in order to improve the quality of graduates who can fill the job opportunities with effectively and efficiently. The purpose of this study is to describe the quality of education to face competition Asian Economic Community (AEC) through the basic concept of qualified theory. Method of this study is descriptive by using literature review analysis. The results of analysis showed that the management of quality-based education in facing the Asian Economic Community. Management of qualified education can produce effective, efficient, productive and qualified graduates' in facing the AEC at various levels of education from basic education to higher education and educational outcomes to have skills and have a useful competitiveness, for the life of a society of both materially and spiritually that can solve various problems.
\end{abstract}

Keywords: management, quality-based education, Asian Economic Community

\section{INTRODUCTION}

Quality education is the main requirement to realize the life of a nation that advanced modern and prosperous. While the quality and quality of education depends on the role and function of teachers in an educational institution, namely professional, prosperous and dignified teachers, including educators and education personnels.

One of the main problems in education in Indonesia this time, is the ineffectiveness of teaching in the education process in schools, due to the following problems: (1) cost of education this is the main problem of education in this country, namely the high cost of education from basic to advance level, this is appears a lot phenomenon of dropping out of school among Indonesian children. Let alone for private schools, for public schools too, the cost of education remains high, BOS assistance options provided by the government are still not able to overcome the problem of the high cost of this education; (2) lack of educational equality in Indonesia for some people, education is common, but for many people in remote areas, education is very luxury and valuable, because in a country that embraces decentralization of irony, education is more focused in the more potential core areas, this causes less equity and makes the gap in education; (3) low quality education facilities and infrastructure, we would have heard a lot of news about schools collapsed, or schools damaged because the building that have weathered but did not get help from the government, this is one proof of how low the quality of educational facilities and infrastructure in Indonesia; and (4) the low achievement of students from research balitbang, the ability of students to capture material in Indonesia only about $30 \%$ of all the material taught. this is influenced by many factors, such as lack of awareness in the world of education and also still lack of knowledge of students about the meaning of an education.

Suci (2013) states poor quality of education based on data $54 \%$ of teachers in Indonesia do not have sufficient qualifications to teach, teachers are the spearhead in improving the quality of education, where teachers will interact landally with learners in learning in the classroom. Through this process of learning and teaching, the quality of education begins. That is, the overall quality of education starts from the quality of learning conducted by teachers in the classroom. In quantity, the number of teachers in Indonesia are sufficient. However, the distribution and quality, generally still low.

Another problem that may affect the role and function of educational outcomes that governments and institutions of education need to address is the problem of the application of the Asian Economic Community (AEC) market, because automatically institutions or educational institutions will tend to be reactive to tight competition in the face of a single Asia market 2015 AEC agreed by the government, although not yet fully accepted by the whole community, because the presence of this market comes with an economic perspective, so people who are outside the economic sphere, can not know or do not want to know about AEC that had been launched on December 31, 2015 ago, allowing easy mobility of goods, services, and people between countries in the region of Southeast Asia. Of course this is a breath of fresh air for those ready to compete, but it becomes a crippling storm for those not prepared to compete.

With the conclusion of the AEC by the government automatically not only easy entry of goods, services, but also the freedom of culture that enters and can affect the social and cultural characteristics of a nation, which may be disturbing cultural preservation and even the loss of a characteristic a nation.

From the background, it can be concluded that the educational problem experienced in Indonesia is the quantity of educators available at a very complex, generally inadequate, especially in primary and secondary education, they are less able to perform their profession competently. They have not succeeded in carrying out their responsibility to educate students systematically through educational processes organized to counter the free market and globalization initiated by the AEC. It appears that the educational process has 
not succeeded in developing the students' overall skills skills, whether physical, mental, or intellectual so that effective, efficient and productive education management is needed in achieving educational goals.

This should be one of the main points of improvement of the education system in Indonesia, since the more advanced a country stems from quality education, quality education boils down to quality learning, quality learning starts from qualified teachers as well. So for the authors interested to explain how the management of quality-based education in the face of the AEC. The theory underlying this writen, on the theory Total Quality Management (TQM) that has an orientation on quality or product results in order to meet customer expectations.

TQM, quality management can be defined as the totality of resource empowerment with the optimal level of effectiveness by simultaneously quality management has characteristics include: (1) discipline, commitment, and consistent in achieving vision; (2) alignment with customers; (3) craving to identify customer problems; (4) Accepting critical suggestions from various parties for improvement; (5) attracting and sympathizing with customers; (6) ability and empowerment of employees; and (7) perfoming continuous improvement of various fields (Tjiptono \& Diana, 2001).

Garvin and Davis state that quality is a dynamic condition associated with results, and labor, in the performance of tasks, consumers (Nasution, 2005). Harsey and Blanchard state that management as working with an trough individuals and group to accomplish organizational goal (Sudjana, 2001). Smith states education can be defined as the organized, systemic effort to foster learning, to estabilish the conditions and provide the activities trough whush learning can occur (Sudjana, 2001). Educational activities that include activities of training skills to think in such a way, to scientific thinking (Muhmidayeli, 2005).

\section{METHODS}

Based on this the authors are interested and try to explain the theoretical study on the management of quality based education, with the method of descriptive study with literature review analysis focus on the study of implementation of quality based education management in facing the AEC according study study as follows:

1. The basic concept of TQM an effort to improve education management system in a changing culture or value system towards better, Scheuing and Christoper argue that every organization needs to carry out continuously (Nasution, 2005);

2. Quality management is the totality of resource empowerment with the level of optimal effectiveness by simultaneously quality management (Tjiptono \& Diana, 2001);

3. Achievement of quality education that has knowledge skills (cognitive), attitude (affective), motion skills (psychomotor skills) and believing skills, operational skills and managerial (magerial skills) (Sanusi, 2014).

\section{RESULT AND DISCUSSION}

Management education, is an activity of empowering various resources that can sustain the process of achieving goals effectively, efficiently and productively using various approaches and strategies by implementing planning, organizing, mobilization and supervision. In general, in the implementation of management education a manager should be able to manage the following: (1) human resources; (2) cost; (3) facilities and infrastructure; and (4) socio-cultural environment of education; and (5) management activities (managerial). In detail can be explained as the following.

\section{Management of Human Resources}

A manager must be able to move the soul and body to conduct a program with a professional who has been determined in order to achieve the goals of an organization or institution that has been established by sharing approaches and strategies by determining the standards that have been set.

This is in line with Harsey and Blanchard opinion management as working with an trough individuals and group to accomplish organizational goal (Sudjana, 2001), so that in the organization formed an active work culture atmosphere, and productive, in accordance with standard or reference criteria that have been set.

\section{Cost Management}

Cost is one of the factors in supporting a goal of an institution or organization in order to finance the activities and activities of the organization in achieving the objectives that have been set so that every activity should be budgeted budget and expenditure with the principle of efficiency, in order to save the source of cost, energy and time with maximum results, in order to create a dynamic condition associated with the results, and labor, in carrying out tasks, consumers (Nasution, 2005), in accordance with the standard quality of products / output produced either in the form of goods or services.

\section{Management of Facilities and Infrastructure}

Facilities and toels are supporting factor for the achievement of an organization or agency objectives related to the availability of supporting tools in the form of software and hardware that can be empowered in the achievement of the goal with effectively and efficiently in order to improve the results of a product or output both in quantity and quality. This goal can be achieved by sufficient adequate resources so that the education process can be implemented in an organized and systematic manner "encourage learning, to establish conditions and provide activities where learning can occur (Sudjana, 2001), so that the goal of education can be achieved optimally as expected.

\section{Management of the Socio-cultural Environment}

Social and cultural environment is one of the elements of the support that must be formed within an organization in achieving a harmonious and dynamic goals that can create a productive, effective, efficient, 
relevant, flexible and sustainable work culture synergy. So that in the implementation of management can be easily to carry out communication, coordination, consolidation and confirmation with various stakeholders, in the sense that an education manager must be able to work together, integrated to create synergy and synchronization with various stakeholders, so it will be easier to: (1) alignment with customers; (2) desire to identify customer problems; (3) accept criticism suggestions from various parties for improvement; (4) can attract and sympathize customers; (5) ability, and empowerment of employees; and (6) perform continuous improvement of various fields (Tjiptono \& Diana, 2001).

\section{Management (Managerial)}

Management is an effort to achieve the goal of education with effectively and efficiently with the maximum achievement by doing activities planning, organizing, mobilization, and supervision, various resources available in achieving educational goals, therefore for managers, educators and learners are expected to think to the ideas / ideas of a result (thought, opinion, theory) are practiced, correctly have value and use, to make improvements, and the results of the changes can meet the needs of his own life and others, while the changes occur with continuously (continues) for a better change, and the process of change can't be denied, because human life is interdependent and the tendency to make communication and interaction both with the environment and each other it is done in an attempt to meet the needs felt in the cultivation panya.

The expected improvement through education includes training skills activities to think in such a way, to scientific thinking (Muhmidayeli, 2005). So that learners can have a valuable learning experience as a provision for life in the future, the skills of knowledge, attitude skills, spirit skills, belief skills, behavioral skills and skills to manage what is owned and controlled in accordance with the competence he mastered as learning achievement is in accordance with the opinion of Sanusi (2014). About the achievement of quality education that is having the skills of knowledge (cognitive), attitude (affective), movement skills (psychomotor) and skills confidence belief (believing skills), operational skills (operational skills) and management (managerial skills).

For the process of achieving the quality of education in this case the need for commitment, consistency and discipline, managers and implementing education, leadership and policy programs that can realize the educational goals set by either the institution or educational institution. the management of the description of the results of the analysis can be described simply by the mindset of education management based on the quality, illustrated Figure 1.

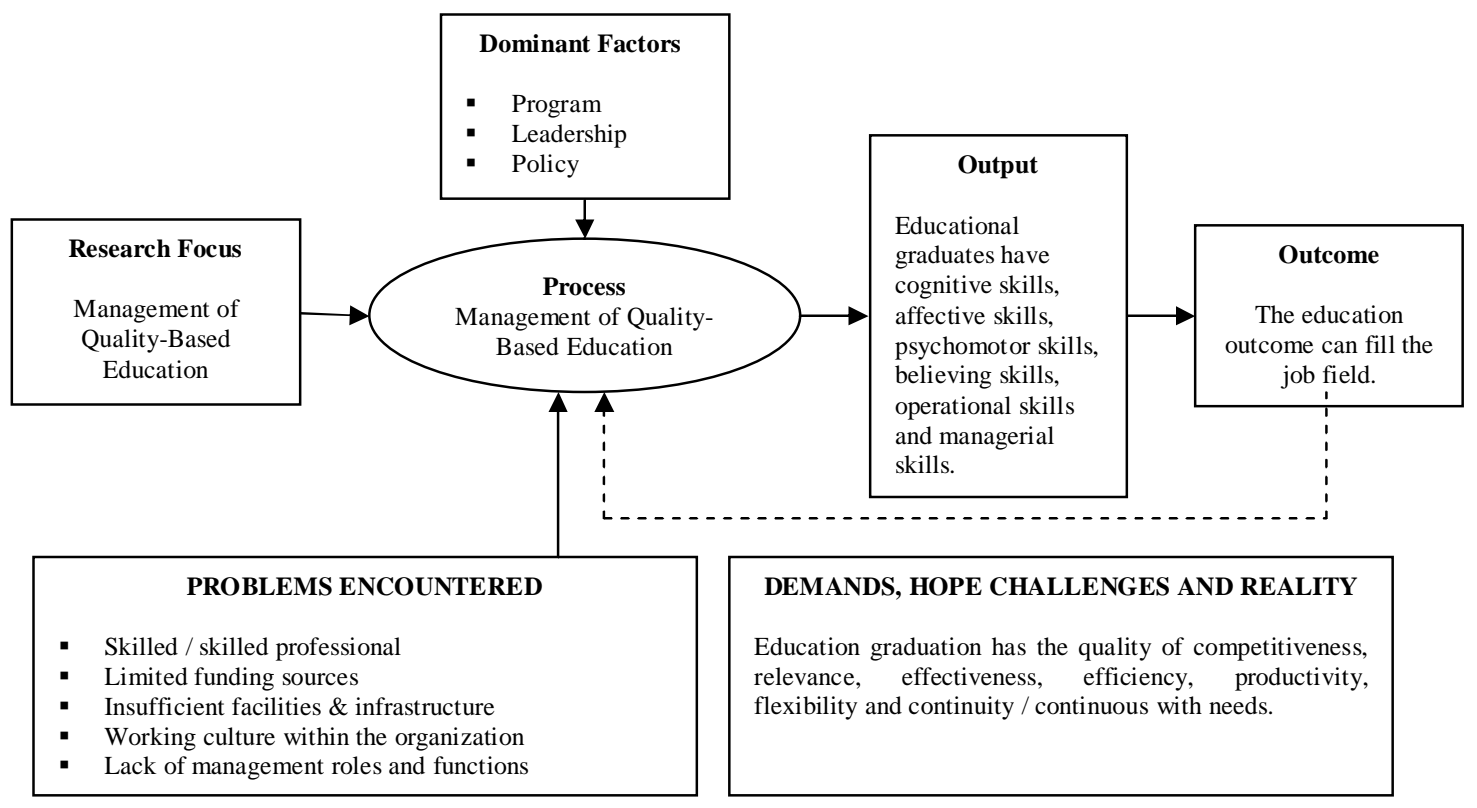

Figure 1

Mindset of Management of Quality Education

\section{CONCLUSION}

The management of quality-based education in the face of the Asian Economic Community (AEC) can be implemented and effectively, efficiently and productively if managers, professional educators can think scientifically in organizing and managing resources covering human resources, cost, and sociocultural environment optimally will produce the quality of graduates who possess the skills of knowledge skills, attitude skills, spirit skills, belief skills, behavioral skills and skills to manage what is owned and controlled in accordance with the competence he mastered as a learning achievement that has the advantage and power competitiveness and able to fill the available jobs. 


\section{REFERENCES}

[1] Abduloh. 2016. Leader of Success in the Modernization of Education. Proceeding The $1^{\text {st }}$ Internationak Conference on Education in Indonesia (ICE).

[2] Abduloh. 2017. Creating Innovation in Education by Using Value Analysis System. Proceeding The Fifth south East Asia Development Research International Conference ( $5^{\text {Th }}$ SEA-DR).

[3] Davis, R., \& Cuttance, P. 1998. School Effectiveness: Research, Policy, and Practice. Trowbrigde, Wilts: Redwood Books.

[4] Muhmidayeli. 2005. Filsafat Pendidikan Islam. Pekan Baru: LSFK2P.

[5] Nasution. 2005. Manajemen Mutu Terpadu (Total Quality Manajemen). Jakarta: Ghalia Indonesia.

[6] Sanusi, A. 2015. Sistem Nilai Alternatif Wajah-wajah Pendidikan. Bandung: Nuansa Cendikia.

[7] Sudjana. 2000. Dasar-dasar Proses Belajar Mengajar. Bandung: PT Sinar Baru Algesindo.

[8] Sudjana. 2002. Penilaian Hasil Proses Belajar Mengajar. Bandung: PT Remaja Rosdakarya.

[9] Tjiptono, F., \& Diana, A. 2001. Total Quality Management. Yogyakarta: ANDI. 